\title{
Penambahan Natrium Metabisulfit (Na2S2O5) terhadap Vitamin C dan Warna pada Proses Pengeringan Cabai Merah (Capsicum annuum L.) dengan Tunnel Dehydrator
}

\author{
Hisworo Ramdania ${ }^{a}$, Reki Wicaksono ${ }^{b}$ dan M. Agus Fachruddin ${ }^{c}$ \\ a Pengajar PS Ilmu dan Teknologi Pangan, Fakultas Bioindustri, Universitas Trilogi, \\ Peneliti Pusat Kajian Hortikultura Tropika (PKHT) Institut Pertanian Bogor \\ ${ }^{\mathrm{b}}$ Staf Pengajar Program Studi Teknologi Industri Pertanian, Fakultas Ilmu Pangan Halal, \\ Universitas Djuanda \\ ${ }^{\mathrm{c}}$ Alumni Program Studi Teknologi Industri Pertanian, Fakultas Ilmu Pangan Halal, Universitas \\ Djuanda Bogor
}

\begin{abstract}
Abstrak
Tujuan penelitian ini adalah untuk mengetahui pengaruh peningkatan Na2S2O5 terhadap vitamin $\mathrm{C}$ dan warna cabai merah (Capsicum annuum L.) yang dikeringkan dalam proses dehidrasi dengan dehidrator terowongan. Penelitian ini telah dilakukan dengan menggunakan desain acak faktorial dengan dua faktor, yaitu: natrium metabisulfit konsentrat $(\mathrm{A} 1=0,1 \%, \mathrm{~A} 2=0,2 \%$, dan A3 $=0,3 \%)$ dan waktu rendam $(\mathrm{B} 1=5$ menit, $\mathrm{B} 2=10$ menit, dan $\mathrm{B} 3=15$ menit $)$. Parameter yang dianalisis adalah vitamin C (Jacobs, 1958) dan warna cabai merah kering (skala Hunter). Natrium metabisulfit terkonsentrasi memiliki efek yang signifikan terhadap vitamin $C(\alpha=0,05)$, dan tidak berpengaruh signifikan terhadap warna cabai merah kering. Lama Perendaman Natrium metabisulfit dan interaksi keduanya tidak memiliki pengaruh signifikan pada vitamin $\mathrm{C}$ dan warna cabai merah kering. Perlakuan terbaik natrium metabisulfit konsentrat A1 (konsentrat $=0,1 \%$ ) adalah efek yang paling signifikan. Perawatan terbaik natrium metabsiulfit waktu rendam adalah B1 (5 menit). Interaksi terbaik keduanya adalah A1B1 (konsentrat $=0,1 \%$ dan 5 menit).
\end{abstract}

Kata kunci: pengeringan, tunnel dehydrator, capsicum, cabai merah

\section{Abstract}

The purpose of this study was to investigate the effect of increasing Na2S2O5 towards vitamin $\mathrm{C}$ and color red chili (Capsicum annuum L.) dried in dehydration process with tunnel dehydrator. The research had been performed using factorial randomized design with two factors, i.e.: natrium metabisulfite concentrates ( $\mathrm{A} 1=0.1 \%, \mathrm{~A} 2=0.2 \%$, and $\mathrm{A} 3=0.3 \%$ ) and soak's time $(\mathrm{B} 1=5$ minute, $\mathrm{B} 2=10$ minute, and $\mathrm{B} 3=15$ minute $)$. Parameters analyzed were vitamin $\mathrm{C}$ (Jacobs, 1958) and color of red chili dry (Hunter scale). Natrium metabisulfite concentrated had significant effect on vitamin $C(\alpha=0.05)$, and had no significant effect on color red chili dried. Soak's time natrium metabisulfite and the interaction both of them had no significant on vitamin $\mathrm{C}$ and color red chili dried. The best treatment of natrium metabisulfite concentrate A1 (concentrate $=0.1 \%$ ) is the most significant effect. The best treatment of soak's time natrium metabsiulfite is B1 (5 minute). The best interactions both of them is A1B1 (concentrate $=0.1 \%$ and 5 minute).

Keywords: drying process, tunnel dehydrator, capsicum, red chili 


\section{Latar belakang}

Cabai (Capsicum annum L.) merupakan tanaman sayuran, yang memiliki kadar air yang cukup tinggi. Pembudidayaan cabai di Indonesia sebagian besar dihasilkan oleh pertanian rakyat, dalam skala besar maupun kecil. Cabai biasanya digunakan dalam bentuk segar maupun kering, untuk bahan bumbu dapur, ramuan obat, kebutuhan industri pangan, dan industri rumah tangga.

Penghasil cabai merah di Indonesia ada dibeberapa daerah, terutama Jawa yang merupakan penghasil utama dan diluar Pulau Jawa seperti di Sulawesi Selatan dan Sumatera Selatan. Produksi cabai Indonesia tahun 2011 sebesar 888,852 ribu ton, mengalami peningkatan sebesar 82,692 ribu ton $(10,12$ persen) dibandingkan dengan tahun 2010. Peningkatan produksi cabai tersebut terjadi di Pulau Jawa sebesar 15,424 ribu ton, sedangkan diluar Pulau Jawa meningkat sebesar 66,268 ribu ton (BPS, 2011).

Cabai merah merupakan komoditas yang rentan terhadap kerusakan, dikarenakan kadar air yang cukup tinggi. Barus (2009) menjelaskan bahwa cabai mudah sekali mengalami kerusakan. Kerusakan pada cabai dapat berasal dari cabai sendiri maupun faktor luar dari cabai tersebut. Petani tidak berani ambil resiko untuk menyimpan hasil panen cabainya karena sifat cabai yang mudah rusak.

Hasil panen budidaya cabai merah dari petani meningkat ketika panen raya, hal ini menyebabkan rendahnya harga jual cabai merah segar dipasaran. Sebaliknya ketika panen raya selesai, maka jumlahnya akan menurun yang menyebabkan harga dari cabai merah segar akan meningkat harganya.

Pengeringan cabai merah dapat dilakukan dengan cara alami dan buatan. Proses pengeringan alami dilakukan dengan memanfaatkan sinar matahari untuk menjemurnya. Pengeringan dengan cara buatan yaitu dengan cara memberikan panas buatan atau mengalirkan udara panas ke bahan. Pengeringan yang dilakukan secara alami sangat berpengaruh terhadap keadaan cuaca setiap musim. Berbeda halnya dengan cara buatan yang tidak tergantung keadaan cuaca.
Pada kapasitas yang besar, pengeringan secara alami memiliki banyak kendala dan memerlukan waktu yang cukup lama untuk mencapai standar kadar air yang ditentukan. Alternatif pengeringan buatan diharapkan dapat menjadi salah satu solusi untuk memenuhi standar cabai merah kering dan mempercepat waktu pengeringan.

Proses pengeringan buatan saat ini telah berkembang dengan pesat, ada beberapa cara yang dapat dilakukan. Cara sederhana yang dilakukan dengan memperoleh panas dari pembakaran kayu bakar atau dengan bahan bakar lain. Proses sederhana ini hanya efektif untuk kapasitas bahan yang rendah. Kapasitas bahan cabai merah dalam skala besar dapat dilakukan dengan menggunakan mesin pengering. Tipe mesin yang berkembang saat ini ada tipe rotary dryer, tray dryer, penangkap energi surya, tipe konveksi, dan lain. Penelitian pengeringan cabai merah ini menggunakan tunnel dehydrator.

Pembuatan tunnel dehydrator dirancang dengan ruang pengering yang lebih luas dan menggunakan rak-rak pengering yang tersusun vertikal. Tunnel dehydrator terdiri dari tiga sub-model yang cocok untuk memperkirakan keadaan suhunya, dan berhasil dikembangkan dan diterapkan dalam program $\mathrm{C} / \mathrm{C}++$. Suhu pengeringan pada tunnel dehydrator dapat diatur sesuai kebutuhan dan ketepatan suhu ketika proses pengeringan dapat terjaga (Unadi, 2000).

Pengeringan secara buatan menggunakan mesin tipe rotary dryer, tray dryer, penangkap energi surya, tipe konveksi, maupun tunnel dehydrator berpengaruh terhadap kandungan dalam cabai seperti berbagai vitamin terutama vitamin $\mathrm{C}$, kadar warna atau karotenoid, dan capsaicin yang rentan terhadap panas. Pengeringan cabai yang menggunakan bahan pencelup dapat mempertahankan warna dan vitamin $\mathrm{C}$ pada cabai kering. Suryatenggara (1989) menerangkan bahwa penggunaan bahan pencelup Na2S2O5 ternyata lebih baik dibandingkan dengan $\mathrm{K} 2 \mathrm{~S} 2 \mathrm{O} 5$ dan $\mathrm{Mg}(\mathrm{OH}) 2$ terutama untuk mempertahankan warna dan vitamin $\mathrm{C}$. 
Penelitian ini diharapkan dapat mendapatkan hasil pengaruh penambahan sulfit (Na2S2O5) terhadap kandungan vitamin $\mathrm{C}$ dan warna pada cabai merah menggunakan tunnel dehydrator. Hasil pengeringan cabai merah ini kemudian akan dianalisis dengan mengamati perubahan kandungan vitamin $\mathrm{C}$ dan warna pada cabai merah kering.

\section{Tujuan penelitian}

Penelitian ini dilakukan untuk mendapatkan pengaruh penambahan natrium metabisulfit $\left(\mathrm{Na}_{2} \mathrm{~S}_{2} \mathrm{O}_{5}\right)$ terhadap kandungan vitamin $\mathrm{C}$ dan warna pada proses pengeringan cabai merah.

\section{Hipotesis}

Ada pengaruh perlakuan konsentrasi, lama perendaman, dan interaksi antara konsentrasi dan lama perendaman natrium metabisulfit $\left(\mathrm{Na}_{2} \mathrm{~S}_{2} \mathrm{O}_{5}\right)$ terhadap vitamin $\mathrm{C}$ dan warna pada proses pengeringan cabai merah.

\section{BAHAN DAN METODE}

\section{Waktu dan Tempat}

Penelitian ini dilaksanakan di Laboratorium PKHT IPB, Jl. Raya Tajur Km. 6, Bogor 16000, Kota Bogor, dimulai pada bulan Desember 2012 sampai dengan Januari 2013.

\section{Alat dan Bahan \\ Alat yang digunakan dalam penelitian ini adalah tunnel dehydrator, timbangan digital (ketelitian $0.1 \mathrm{~g}$ ), plastik kedap udara, hygrometer, stopwatch, colour reader CR-10 Konica Minolta dan alat-alat uji Vitamin C. Bahan yang digunakan adalah cabai merah varietas cabai keriting, natrium metabisulfit $\left(\mathrm{Na}_{2} \mathrm{~S}_{2} \mathrm{O}_{5}\right)$ dengan konsentasi $0.1 \%, 0.2 \%$ dan $0.3 \%$ dan bahan kimia lain untuk pengujian cabai segar dan kering.}

\section{Metode Penelitian}

Penelitian ini digunakan model Rancangan Acak Faktorial dengan 2 faktor (konsentrasi $\mathrm{Na}_{2} \mathrm{~S}_{2} \mathrm{O}_{5}$ dan lama perendaman), dimana masing-masing faktor terdiri dari 3 taraf perlakuan dengan 2 kali ulangan. Data yang diperoleh dari penelitian ini meliputi kadar vitamin $\mathrm{C}$ dan warna akan dianalisis menggunakan sidik ragam (ANOVA) dengan taraf signifikansi $\quad \alpha=0.05$ dan $\quad \alpha=0.01$, kemudian dilakukan analisis lanjutan dengan Uji BNT (Beda Nilai Terkecil) untuk mengetahui perbedaan antar perlakuan. Uji BNT (Beda Nilai Terkecil) dapat dilakukan jika hasil analisis ragam minimal pengaruh nyata. Model matematisnya adalah sebagai berikut :

$$
\hat{\gamma}_{i j k}=\mu+A_{i}+B_{j}+(\mathrm{AB})_{i j}+\varepsilon_{i j k}
$$

Keterangan:

$\begin{aligned} \hat{Y}_{i j k}= & \text { Hasil pengamatan dari faktor pada } \\ & \text { taraf ke- } i \text { faktor A taraf ke- } j \text { faktor B } \\ & \text { ulangan ke- } k \\ \mu \quad= & \text { Pengaruh rata-rata umum } \\ A i \quad= & \text { Pengaruh taraf ke- } i \text { faktor A } \\ B j \quad= & \text { Pengaruh taraf ke- } j \text { faktor B } \\ (\mathrm{AB}) i j= & \text { Pengaruh interaksi antara taraf ke-i } \\ & \text { faktor A dan taraf ke-j faktor B } \\ = & \text { Efek galat percobaan pada taraf ke- } i \\ & \text { faktor A taraf ke- } j \text { faktor B ulangan } \\ & \text { ke- } k\end{aligned}$

Penentuan kondisi optimum faktor suhu blansir dan lama blansir terhadap kandungan vitamin $\mathrm{C}$ dan warna dilakukan dengan menganalisis permukaan respon nilai vitamin C dan warna yang dipengaruhi oleh faktor reaksi menggunakan Metode Permukaan Respon (RSM). Model rancangan percobaan untuk mengetahui permukaan respon pengaruh faktor adalah sebagai berikut :

$$
Y=a_{o}+\sum_{i=1}^{k} a_{i} X_{i}+\sum_{i=1, j=2}^{k-1, k} a_{i, j} X_{i} X_{j}+\sum_{i=1}^{k} a_{i i} X_{i}^{2}+\varepsilon
$$

Keterangan:

$$
\begin{array}{ll}
\mathrm{Y} & =\text { Respon pengamatan } \\
\mathrm{ao} & =\text { Intersep } \\
\mathrm{ai} & =\text { Pengaruh linier } \\
\text { aii } & =\text { Pengaruh kuadratik } \\
\text { aij } & =\text { Pengaruh interaksi percobaan } \\
\mathrm{Xi} & =\text { Kode untuk faktor ke-i } \\
\mathrm{Xj} & =\text { Kode untuk faktor ke-j } \\
\mathrm{k} & =\text { Jumlah faktor yang dicobakan }
\end{array}
$$

\section{Pelaksanaan Penelitian}

Persiapkan cabai merah keriting sebanyak $5 \mathrm{~kg}$ lalu dilakukan penyortiran, untuk memisahkan bahan yang rusak untuk diproses pengeringan. Cabai yang utuh dicuci untuk menghilangkan kandungan pestisida 
yang menempel pada cabai. Cabai ditiriskan untuk mengurangi air yang tidak terikat pada bahan. Cabai ditimbang dan membaginya ke 10 rak dengan berat yang sama tiap rak sekitar 485 gr. Setiap 485 gr cabai dilakukan perlakuan perendaman dengan menambahkan sulfit (Na2S2O5) $0.1 \%, 0.2 \%, 0.3 \%$ dengan waktu 5 menit, 10 menit dan 15 menit. Kode masing-masing A1B1, A1B2, A1B3, A2B1, A2B2, A2B3, A3B1, A3B2, dan A3B3. Cabai yang telah dilakukan perlakuan lalu dihamparkan cabai di atas rak, dan ditempelkan label kode tiap rak untuk menandai perlakuan pada cabai.

Alat pengering dipersiapkan dengan mengatur suhu pengeringan yang stabil pada suhu $70^{\circ} \mathrm{C}$. Cabai pada rak dimasukkan ke ruang pengering pada mesin, lalu diperhatikan waktu pengeringannya dengan menggunakan stopwatch selama 8 jam sampai cabai kering yang memiliki kadar air sekitar $11 \%$ atau secara sederhana ditandai dengan mudahnya cabai kering untuk dipatahkan.

Pengaruh lama perendaman dapat diketahui dengan melakukan penambahan $\mathrm{Na} 2 \mathrm{~S} 2 \mathrm{O} 5$ konsentrasi $0.1 \%, 0,2 \%$, dan $0.3 \%$ terhadap kandungan vitamin $\mathrm{C}$ dan warna pada proses pengeringan cabai merah (Capsicum annum L.) menggunakan mesin pengering tunnel dehydrator. Analisis yang dilakukan meliputi kadar air (AOAC, 1984), kadar vitamin C (Jacobs, 1985). Pengukuran warna dengan metode Hunter Scale.

\section{.HASIL DAN PEMBAHASAN}

\section{Karakteristik Cabai Merah Segar}

Cabai Cabai merah (Capsicum annuum L.) segar dianalisis untuk mengetahui kondisi awal cabai yang akan dijadikan bahan penelitian. Analisis yang dilakukan meliputi pengujian kadar vitamin $\mathrm{C}$, warna, dan kadar air. Hasil analisis cabai merah segar dilakukan untuk mengetahui pengaruh yang terjadi sebelum proses penelitian.
Tabel 1 Hasil Analisis Cabai Merah (Capsicum annuum L.) Segar

\begin{tabular}{|c|c|c|c|c|c|}
\hline \multirow{3}{*}{ Kode } & \multicolumn{5}{|c|}{ Kondisi Awal } \\
\hline & \multirow{2}{*}{$\begin{array}{c}\text { Vitamin C } \\
(\mathrm{mg} / 100 \mathrm{gr})\end{array}$} & \multicolumn{3}{|c|}{ Warna } & \multirow{2}{*}{$\begin{array}{c}\text { Kadar air } \\
\% \text { wb }\end{array}$} \\
\hline & & $\mathrm{L}$ & $\mathrm{a}$ & B & \\
\hline X0 & 11.22 & 33.95 & 22.25 & 15 & 91.00 \\
\hline A1B1 & 12.32 & 34.1 & 22.15 & 14.15 & 90.50 \\
\hline A1B2 & 14.52 & 34.2 & 22.2 & 14.7 & 90.50 \\
\hline A1B3 & 15.4 & 34.05 & 24 & 15 & 90.75 \\
\hline A2B1 & 11 & 33.95 & 23.05 & 15.15 & 90.50 \\
\hline A2B2 & 14.52 & 34.1 & 23.45 & 14.75 & 90.50 \\
\hline A2B3 & 11 & 34.1 & 24.7 & 15.2 & 90.75 \\
\hline A3B1 & 11.88 & 33.55 & 22.05 & 14 & 90.50 \\
\hline A3B2 & 11.44 & 34.4 & 22.15 & 16.05 & 92.62 \\
\hline A3B3 & 11.88 & 35.5 & 22.55 & 13.45 & 90.50 \\
\hline
\end{tabular}

\section{Kadar Vitamin C}

Hasil analisis vitamin $\mathrm{C}$ cabai merah (Capsicum annuum L.) segar diuji dengan annova, menunjukkan bahwa kadar vitamin $\mathrm{C}$ cabai merah segar tidak berbeda nyata. Kondisi cabai merah segar yang tidak berbeda nyata menunjukkan cabai yang digunakan dapat dilakukan proses lanjut untuk pengeringan. Kadar vitamin $\mathrm{C}$ cabai merah (Capsicum annuum L.) segar menurut Dinas Pertanian dan Pengolahan (2009) adalah 18 $\mathrm{mg} / 100 \mathrm{gr}$. Hasil dari pengujian sampel kadar vitamin $\mathrm{C}$ bahan dibawah standar, hal ini disebabkan cabai merah segar yang digunakan adalah hasil panen terakhir cabai merah petani daerah Desa Megamendung dan proses pengujian dilakukan setelah cabai didiamkan selama 2 hari, sehingga ada respirasi kandungan cabai seperti vitamin $\mathrm{C}$ dan kadar air.

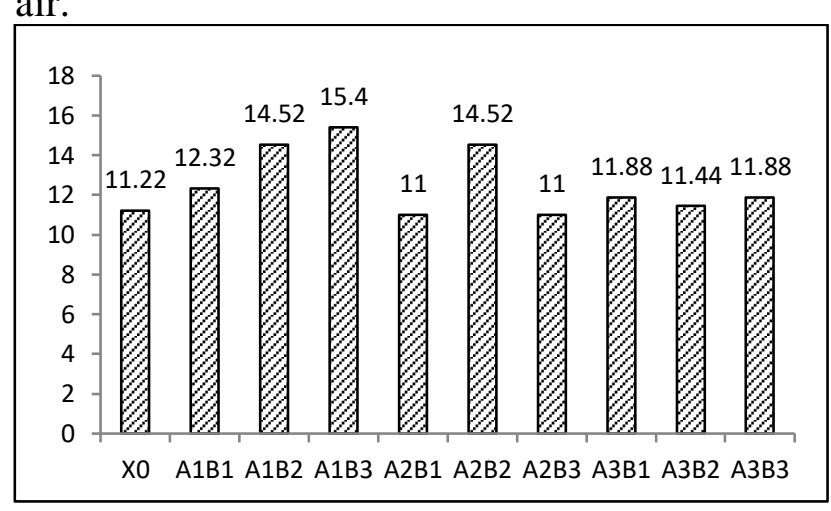

Gambar 1 Kadar Vitamin C Cabai Merah Segar 


\section{Pengukuran Warna}

Hasil Warna pada cabai diukur dengan menggunakan metode hunter scale, dengan mengukur nilai L yaitu tingkat kecerahan sampel. Sampel yang diukur semakin cerah, ketika nilai L mendekati 100. Sampel yang diukur semakin gelap, ketika nilai L mendekati 0 . Hasil pengukuran menunjukkan nilai $\mathrm{L}$ (kecerahan) tertinggi yaitu pada perlakuan A3B3 (konsentrasi $0.3 \%$ dan lama perendaman 15 menit).

Nilai a pada pengukuran warna yaitu parameter campuran merah-hijau pada sampel. Nilai a positif, maka sampel menunjukkan warna lebih merah. Nilai a negatif, menunjukkan warna sampel lebih hijau. Hasil pengukuruan warna pada cabai merah segar, nilai $b$ menunjukkan warna merah. Nilai $b$ tertinggi yaitu pada perlakuan A2B3 (konsentrasi $0.2 \%$ dan lama perendaman 15 menit).

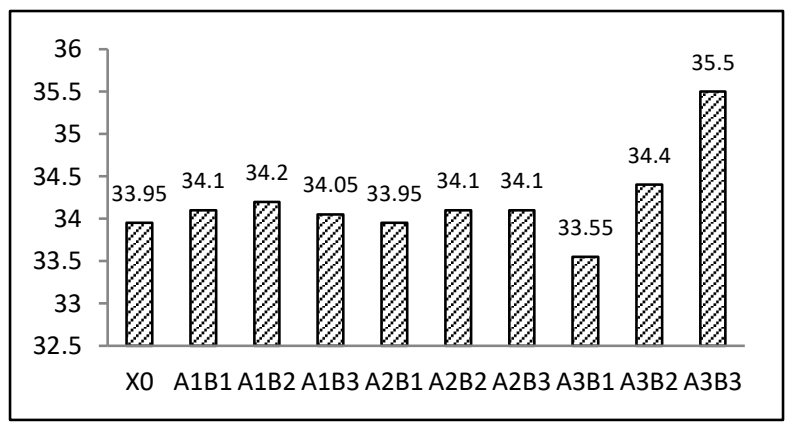

Gambar 4 Nilai L (Kecerahan) Cabai Merah Segar

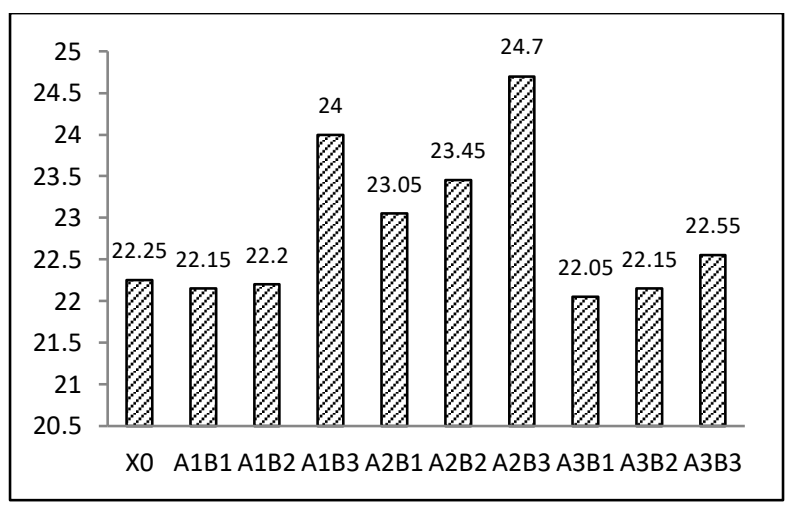

Gambar 5 Nilai a (Merah-Hijau) Cabai Merah Segar

Pengukuran warna pada nilai $b$ menunjukkan warna kuning-biru. Nilai b positif, maka warna sampel lebih kuning dan nilai $b$ negatif maka warna sampel lebih biru.
Hasil pengukuran nilai b pada sampel cabai merah segar menunjukkan warna kuning. Nilai b tertinggi pada perlakuan A3B2 (konsentrasi $0.3 \%$ dan lama perendaman 10 menit).

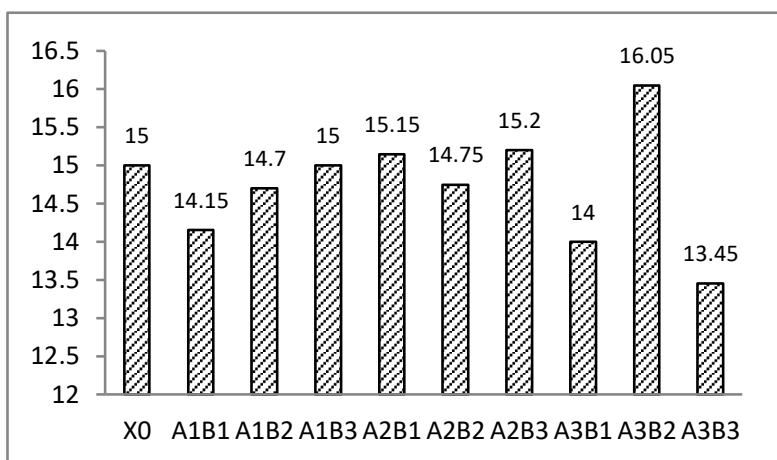

Gambar 6 Nilai b (Kuning-Biru) Cabai Merah Segar

\section{Kadar Air Cabai Merah Segar}

Faktor yang mempengaruhi proses pengeringan cabai merah adalah kadar air. Tujuan pengeringan untuk mengurangi kadar air pada cabai merah, kadar air yang rendah menghambat perkembangan organisme pembusuk. Kadar air suatu bahan berpengaruh terhadap banyaknya air yang diuapkan dan lamanya proses pengeringan (Taib, dkk., 1988).

Hasil data pengukuran kadar air dengan metode oven yang ditampilkan pada Tabel 6, kadar air cabai merah rata-rata sebesar $90,81 \%$. Kadar air pada cabai merah merah (Capsicum annuum L.) segar menurut Direktorat Gizi RI (1981) yaitu sebesar 90.9\%. Analisis keragaman kadar air cabai merah segar pada Lampiran 5 menunjukkan hasil tidak berbeda nyata di setiap perlakuan.

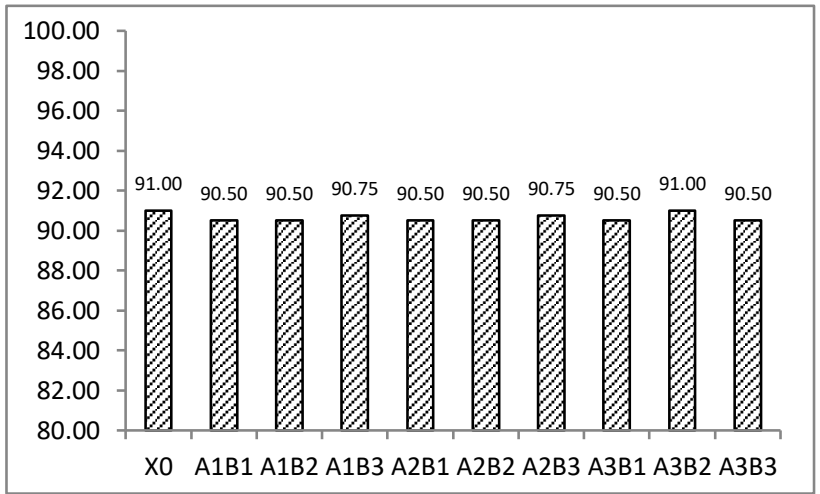

Gambar 7 Kadar Air Cabai Merah Segar $(\% \mathrm{wb})$ 


\section{Pengaruh Perendaman Natrium Metabisulfit Terhadap Parameter yang Diamati}

Parameter yang diamati pada cabai merah (Capsicum annuum L.) kering adalah kadar vitamin C, warna, dan kadar air. Hasil pengukuran vitamin $\mathrm{C}$ dengan metode titrasi, pengukuran warna dengan metode Hunter Scale, dan pengukuran kadar air dengan metode oven dapat dilihat pada Tabel 7. Hasil pengukuran setiap parameter dilakukan analisis statistika untuk mengetahui pengaruh dari perendaman dengan natirum metabisulfit terhadap parameter yang diamati. Hasil analisis statistik untuk mengetahui pengaruh perendaman natrium metabisulfit terhadap parameter dilakukan uji lanjut Beda Nilai Terkecil (BNT).

Tabel 7 Hasil Analisis Cabai Merah (Capsicum annuum L.) Kering

\begin{tabular}{cccccc}
\hline & \multicolumn{5}{c}{ Kondisi Akhir } \\
\cline { 2 - 5 } Kode & $\begin{array}{c}\text { Vitamin C } \\
(\mathrm{mg} / 100 \mathrm{gr})\end{array}$ & $\mathrm{L}$ & $\mathrm{a}$ & $\mathrm{b}$ & Warna \\
\cline { 3 - 5 } X0 & 17.60 & 32.55 & 13.4 & 11.65 & 11.11 \\
A1B1 & 17.60 & 32.7 & 11.35 & 12.05 & 5.26 \\
A1B2 & 18.48 & 31 & 11.6 & 11.55 & 5.26 \\
A1B3 & 18.04 & 31.15 & 11.35 & 11.45 & 8.19 \\
A2B1 & 18.48 & 32.55 & 9.95 & 12.25 & 5.26 \\
A2B2 & 16.72 & 30.55 & 12.4 & 11.35 & 5.26 \\
A2B3 & 14.52 & 32.3 & 11.75 & 12.5 & 8.19 \\
A3B1 & 16.28 & 31.65 & 13.2 & 12.25 & 5.26 \\
A3B2 & 14.52 & 31.8 & 13.7 & 12.20 & 8.19 \\
A3B3 & 12.76 & 31.9 & 10.4 & 11.35 & 5.26 \\
\hline
\end{tabular}

\section{Kadar Vitamin C}

Kadar vitamin $C$ pada cabai mudah rusak dengan adanya pemanasan dan larut dalam air. Kadar vitamin C cabai kering dilakukan analisis keragaman, hasil analisis keragaman perendaman natrium metabisulfit yaitu konsentrasi dan lama perendaman terhadap kadar vitamin $\mathrm{C}$ dengan tingkat kepercayaan 95\% pada Lampiran 2 menunjukan bahwa konsentrasi natrium metabisulfit berpengaruh nyata terhadap kadar vitamin $\mathrm{C}$, sedangkan lama perendaman natrium metabisulfit tidak berpengaruh nyata dan interaksi keduanya tidak berpengaruh nyata terhadap kadar vitamin $C$ pada $\alpha=0.05$ dan $\alpha=0.01$. Hasil uji lanjut untuk konsentrasi natrium metabisulfit menggunakan uji Beda Nilai Terkecil (BNT) dengan taraf uji 95\% menunjukan pada taraf A1 (konsentrasi 0.1\%) merupakan hasil optimal yang berbeda nyata dengan A2 (konsentrasi 0.2\%) dan A3 (konsentrasi 0.3\%). Hasil pengukuran rata-rata kadar vitamin $\mathrm{C}$ pada taraf A1 (konsentrasi 0.1\%) yaitu 18.48 $\mathrm{mg} / 100 \mathrm{gr}$.

Hasil pengukuran vitamin $\mathrm{C}$ pada cabai merah kering rata-rata $18.48 \mathrm{mg} / 100 \mathrm{gr}$ masih dibawah standar yang ditetapkan Ditjen Bina Pengolahan dan Pemasaran Hasil Pertanian (2004) yaitu $50 \mathrm{mg} / 100 \mathrm{gr}$. Vitamin C pada cabai merah kering yang dibawah standar dikarenakan kemungkinan adanya perbedaan varietas yang dijadikan sampel pengukuran, cabai merah (Capsicum annuum L.) yang dijadikan bahan penelitian merupakan hasil panen terakhir dari petani cabai didaerah Megamendung, dan bahan didapatkan pada hari sabtu pagi kemudian dilakukan proses pengeringan pada hari senin ( 2 hari sebelum proses pengeringan).

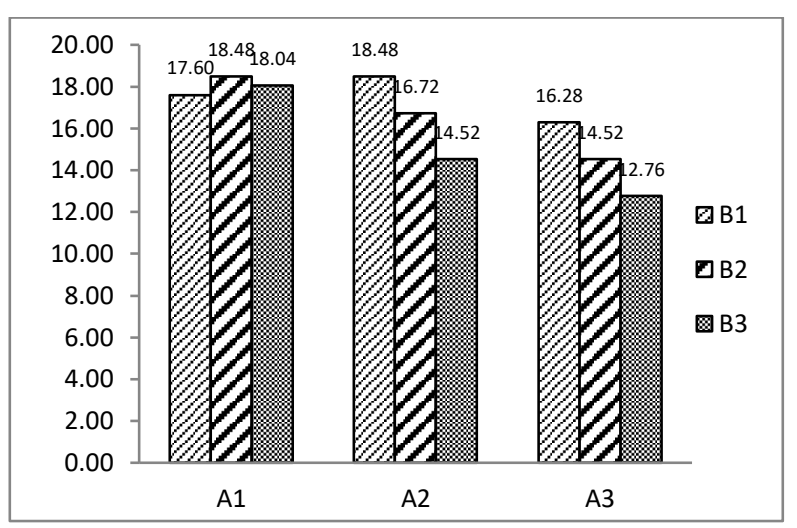

Gambar 29 Pengaruh Perendaman Natrium Metabisulfit Terhadap Kadar Vitamin C Cabai Kering pada Taraf A.

Data rata-rata kadar vitamin $\mathrm{C}$ pada gambar 31 menunjukkan bahwa kadar vitamin C dengan perlakuan konsentrasi dan lama perendaman natrium metabisulfit pada perlakuan A1B2 (konsentrasi 0.1\% dan lama perendaman 10 menit), A1B3 (konsentrasi $0.1 \%$ dan lama perendaman 15 menit), dan A2B1 (konsentrasi $0.2 \%$ dan lama perendaman 5 menit) lebih baik dibandingkan dengan kontrol dan perlakuan yang lain. Hasil rata-rata vitamin $\mathrm{C}$ pada taraf A3 (konsentrasi $0.3 \%$ ) yaitu A3B1 (lama perendaman 5 menit), A3B2 (lama perendaman 10 menit), dan A3B3 (lama perendaman 15 menit) menunjukkan kadar vitamin $\mathrm{C}$ paling kecil yaitu 14.52 $\mathrm{mg} / 100 \mathrm{gr}$ dibandingkan dengan kadar vitamin $\mathrm{C}$ rata-rata kontrol dan perlakuan lain, hal ini disebabkan karena pada taraf perlakuan lama 
perendamannya paling tinggi yaitu sekitar 15 menit. Hasil vitamin C yang dipengaruhi oleh lama perendaman dalam air ini sesuai dengan pernyataan Almatsier (2001) yang menjelaskan bahwa vitamin $\mathrm{C}$ dapat mengalami kerusakan dengan lama penyimpanan, perendaman dalam air, pemanasan dalam waktu lama, dan pemanasan yang terbuat dari besi atau tembaga.

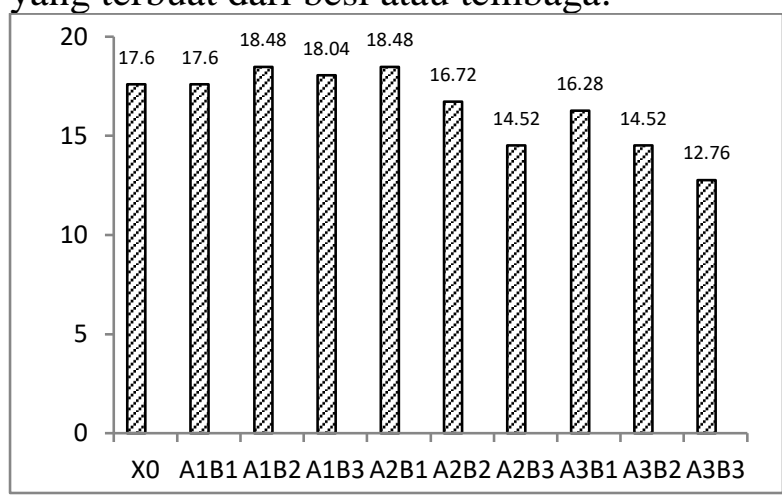

Gambar 30 Hasil Kadar Vitamin C Rata-Rata pada Cabai Merah Kering

\section{Warna}

Terikat Nilai L.a.b (warna) cabai kering dilakukan analisis keragaman, hasil analisis keragaman perendaman natrium metabisulfit yaitu konsentrasi dan lama perendaman terhadap warna cabai merah kering dengan tingkat kepercayaan $95 \%$ pada Lampiran 4 menunjukan bahwa perlakuan tidak berpengaruh nyata dan interaksi keduanya tidak berpengaruh nyata terhadap warna cabai merah kering pada $\alpha=0.05$ dan $\alpha=0.01$.

Warna pada cabai merah (Capsicum annuum L.) kering tidak dipengaruhi oleh lama perendaman dan konsentrasi dengan penambahan natrium metabisulfit dalam air, hasil ini sesuai dengan pernyataan (Dutta, Chaudhuri, dan Chakraborty, 2005) yang menjelaskan bahwa senyawa karotenoid yang terdapat dalam buah-buahan berwarna merah merupakan zat yang tetapi tidak larut dalam air, gliserol, dan propilen glikol.

Data yang dihasilkan pada pengeringan cabai merah menunjukkan bahwa warna tidak dipengaruhi perlakuan perendaman menggunakan natrium metabisulfit. Nilai ratarata $\mathrm{L}$ (kecerahan) pada cabai merah kering perlakuan A1B1 (konsentrasi $0.1 \%$ dan lama perendaman 5 menit) menunjukkan nilai $\mathrm{L}$ (kecerahan) lebih baik dibandingkan dengan kontrol. Perlakuan A2B1 (konsentrasi 0.2\% dan lama perendaman 5 menit) hasil nilai $\mathrm{L}$ (kecerahan) menunjukkan hasil data rata-rata yang sama dengan nilai L pada kontrol, warna pada cabai merah kering ini sesuai dengan Wardani, et. all (2008) yang menjelaskan untuk mempertahankan warna cabai merah agar tetap baik adalah dengan melakukan perendaman larutan bisulfit $0.2 \%$ selama 5-10 menit.

Hasil pengukuran nilai L (kecerahan) pada cabai merah kering tertinggi yaitu pada perlakuan A1B1 (konsentrasi 0.1\% dan lama perendaman 5 menit).

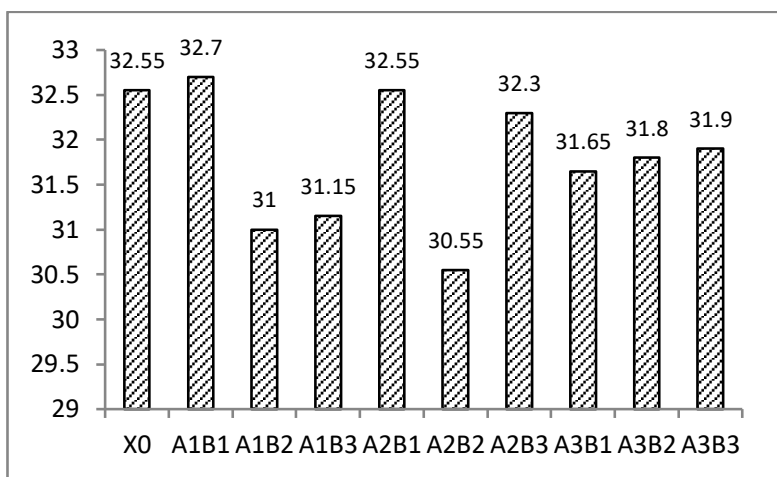

Gambar 31 Nilai L (Kecerahan) pada Cabai Merah Kering

Nilai a pada pengukuran warna yaitu parameter campuran merah-hijau pada sampel. Nilai a positif, maka sampel menunjukkan warna lebih merah. Nilai a negatif, menunjukkan warna sampel lebih hijau. Hasil pengukuruan warna pada cabai merah segar, nilai $b$ menunjukkan warna merah. Nilai $b$ tertinggi yaitu pada perlakuan A3B2 (konsentrasi $0.3 \%$ dan lama perendaman 10 menit).

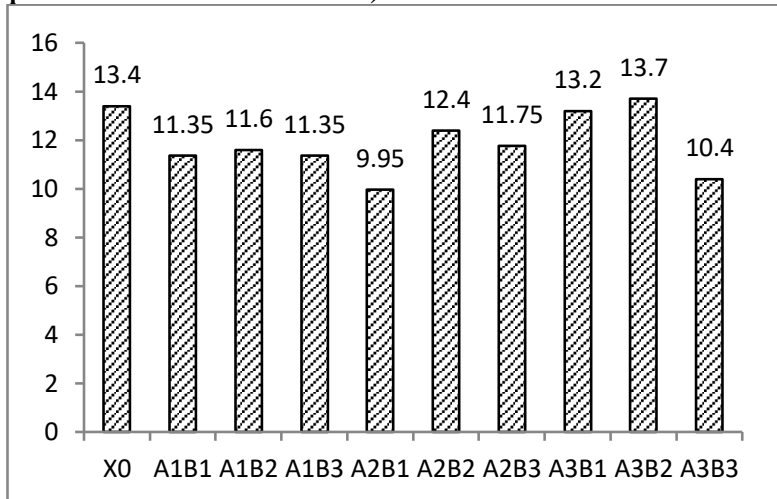

Gambar 32 Nilai a (Merah-Hijau) pada Cabai Merah Kering 
Pengukuran warna pada nilai $b$ menunjukkan warna kuning-biru. Nilai b positif, maka warna sampel lebih kuning dan nilai b negatif maka warna sampel lebih biru. Hasil pengukuran nilai b pada sampel cabai merah segar menunjukkan warna kuning. Nilai $\mathrm{b}$ tertinggi pada perlakuan A3B2 (konsentrasi $0.3 \%$ dan lama perendaman 10 menit).

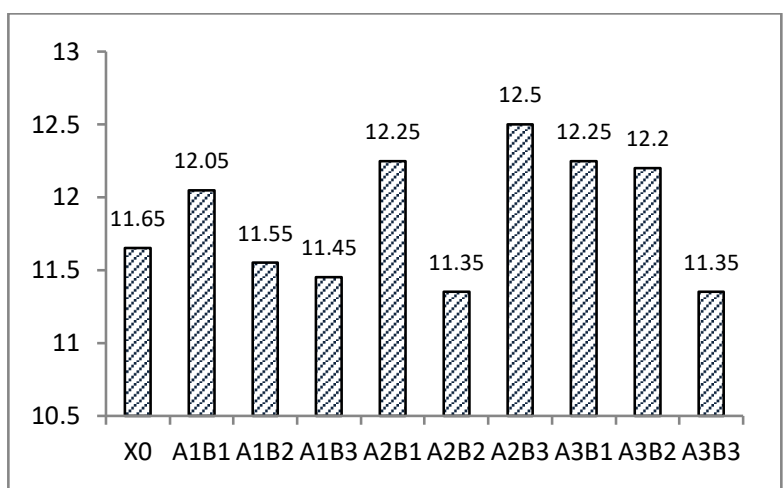

Gambar 33 Nilai b (Kuning-Biru) pada Cabai Merah Kering

\section{Kadar Air Cabai Merah Kering}

Kadar air pada cabai merah kering dijadikan dasar untuk menentukan ketahanan atau lama penyimpanannya. Adawyah (2007) menjelaskan proses pengeringan adalah untuk mengurangi kadar air pada bahan yang akan dikeringkan. Kadar air yang diharapkan yaitu sampai batas perkembangan mikroorganisme dan kegiatan enzim yang dapat menyebabkan kebusukan. Perkembangan mikroorganisme akan terhambat atau bahkan terhenti sama sekali, sehingga bahan yang dikeringkan mempunyai waktu simpan lebih lama.

Hasil pengukuran kadar air cabai merah (Capsicum annuum L.) kering pada tabel 7. Kadar air rata-rata disetiap perlakuan yaitu sebesar $6,7 \%$ db. Hasil pengukuran tersebut dilakukan analisis keragaman, hasil analisis dapat dilihat pada Lampiran 5. Analisis keragaman perendaman natrium metabisulfit terhadap kadar air tidak menunjukkan pengaruh nyata.

Kadar air cabai merah (Capsicum annuum L.) kering sebesar $6,7 \%$ db sesuai dengan standar mutu cabai kering (SNI 013389-1994) maksimal kadar airnya sebesar $11 \%$.

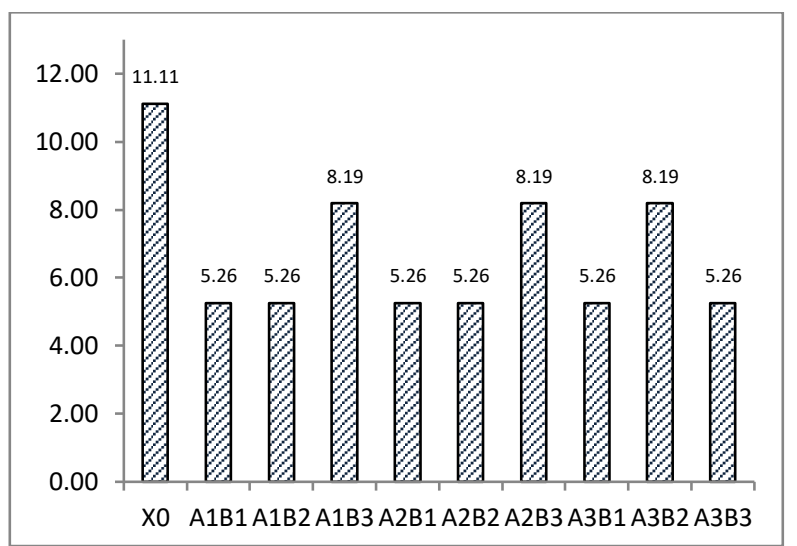

Gambar 35 Kadar Air Cabai Merah Kering (\%db)

\section{KESIMPULAN DAN SARAN}

\section{Kesimpulan}

Blansir Perendaman natrium metabisulfit sebelum proses pengeringan cabai merah menggunakan tunnel dehiydrator dengan parameter yang diamati yaitu kadar vitamin $\mathrm{C}$ dan warna pada cabai merah kering. Hasil pengujian memberikan pengaruh nyata pada perlakuan konsentrasi natrium metabisulfit (taraf A) terhadap parameter kadar vitamin C. Perlakuan lama perendaman (taraf B) dan interaksi antara keduanya tidak berpengaruh nyata terhadap kadar vitamin $\mathrm{C}$ cabai merah kering. Perlakuan konsentrasi dan lama perendaman tidak memberikan pengaruh nyata terhadap warna cabai merah kering.

Hasil uji lanjut Beda Nilai Terkecil (BNT) perlakuan konsentrasi natrium metabisulfit terhadap kadar vitamin $\mathrm{C}$ cabai kering menunjukkan pada taraf A1 (konsentrasi $0.1 \%$ ) memberikan hasil yang terbaik dengan nilai rata-rata kadar vitamin C yaitu $18.04 \mathrm{mg} / 100 \mathrm{gr}$ dan lebih baik dari ratarata kadar vitamin $\mathrm{C}$ kontrol yaitu 17.60 $\mathrm{mg} / 100 \mathrm{gr}$. Berdasarkan data yang dihasilkan pada pengeringan cabai merah menunjukkan bahwa warna tidak dipengaruhi perlakuan perendaman menggunakan natrium metabisulfit. Nilai rata-rata L (kecerahan) pada cabai merah kering perlakuan A1B1 (konsentrasi $0.1 \%$ dan lama perendaman 5 menit) menunjukkan nilai L (kecerahan) lebih baik dibandingkan dengan kontrol. 


\section{Saran}

Penelitian tentang pengeringan cabai merah keriting dengan melakukan perlakuan blansir masih memiliki banyak kekurangan, diantaranya :

1. Perlu diteliti lebih lanjut mengenai residu penggunaan natrium metabisulfit terhadap cabai merah kering yang dihasilkan.

2. Perlu dilakukan penelitian lanjut mengenai umur simpan cabai merah kering yang dihasilkan.

\section{DAFTAR PUSTAKA}

[AOAC] Association of Official Agricultural Chemist. 1984. Official Nethods of Analysis. Washington DC, USA.

Almatsier, S. 2001. Prinsip Dasar Ilmu Gizi. Jakarta: Gramedia Pustaka Utama.

Anonim. 2010. Pengeringan, Pendinginan dan

Pengendalian Mutu.

http://bos.fkip.uns.ac.id/pertanian/peng endalian-mutu/pengeringanpendinginan-dan-pengemasankomoditas-pertanian.pdf. [20 Maret 2012]

Adawyah. R. 2007. Pengolahan dan Pengawetan Ikan. Jakarta: Bumi Aksara.

[AOAC] Association of Official Agricultural Chemist. 1984. Official Methods of Analysis. Washington DC, USA.

Barus, M.V. 2009. Studi tentang pengetahuan dan tata cara pengelolaan petani cabai di Desa Batu Karang, Kecamatan Payung, Kabupaten Karo [skripsi]. Medan: Program Sarjana, Universitas Sumatera Utara.

[BPS] Badan Pusat Statistik. 2011. Produksi Cabai Besar, Bawang Merah, Dan Mangga Tahun 2011. Jakarta: BPS

Direktorat Jenderal BinaPengolahan dan Pemasaran Hasil Pertanian. 2004. Buletin teknopro hortikultura edisi 65 . http://203.190.36.25/ xplore/view.php?file=PENGOLAHAN -HASIL/PENGOLAHAN\% 20HASIL/2-

Teknologi\%20Proses/Buletin\%20Tekn opro\% 20 Horti

kultura/Buletin\%20Teknopro\%20-
$\% 20$ cabe\%20\%20(1).doc. [ 10 Agustus 2011].

Dutta D, Chaudhuri UR, Chakraborty R. 2005. Structure, health benefits, antioxidant property and processing and storage of carotenoids. African J Biotech 4 (13): 1,510-1,520.

Hartuti, Nur dan R. M. Sinaga. A. 1997. Pengeringan Cabai. Bandung: Balai Penelitan Tanaman Sayuran, Pusat Penelitian dan Pengembangan Hortikultura, Badan Penelitian dan Pengembangan Pertanian.

Haryati, A. Pengaruh penambahan sulfit $\left(\mathrm{Na}_{2} \mathrm{~S}_{2} \mathrm{O}_{5}\right)$ terhadap kerusakan vitamin $\mathrm{C}$ permen jelly gelatin jambu biji (Psidium guajava L.) [skripsi]. Bogor: Fakultas Pertanian, Institut Pertanian Bogor.

Jacobs, MB. 1958. The Chemical Analysis of Foods and Food Products, $2^{\text {nd }}$ Ed. New York: D. Van Nostrand Co., Inc.

Khairunnisa. 2011. Pengaruh pretreatments pada pengeringan cabai merah (Capsicum annuum L.) dengan mesin pengering tipe rak (tray dryer) [skripsi]. Bogor: Fakultas Teknologi Pertanian, Institut Pertanian Bogor.

Maryanto. 1998. Karakteristik Pengeringan Cabai Merah (Capsicum annum). Agri Journal 5: 7-18.

Muchtadi Tien R. 1989. Petunjuk Laboratorium Teknologi Proses Pangan. Bogor: Depdikbud PAU IPB.

Prayudi, B. 2010. Budidaya dan Pasca Panen Cabai Merah (Capsicum annum L.). Jawa Tengah: Badan Penelitian dan Pengembangan Pertanian, Balai Pengkajian Teknologi Pertanian.

Rahman, Farida. 2007. Pengaruh konsentrasi natrium metabisulfit dan suhu pengeringan terhadap mutu pati biji alpukat (Persea Americana mill.) [skripsi]. Sumatera Utara: Departemen Teknologi Pertanian, Fakultas Pertanian, Universitas Sumatera Utara.

Rahman dan Yuyun. 2005. Penanganan Pascapanen Cabai Merah. Yogyakarta: Kanisius.

Setiadi. 2006. Bertanam cabai (edisi revisi). Jakarta: Penebar Swadaya. 
Suhardi dan P. Hastuti. 1982. Pengaruh perlakuan pendahuluan pada pembuatan saribuah manggis. Yogyakarta: Balai Penelitian Tanaman Pangan.

Suharto. 1991. Teknologi Pengawetan Pangan. Jakarta: Rineka Cipta.

Suryatenggara, A. 1989. Mempelajari bahan pencelup dan tingkat kematangan terhadap mutu cabai rawit (Capsicum frutescens L.) kering [skripsi]. Bogor: Fakultas Teknologi Pertanian, Institut Pertanian Bogor.

Syafriandi. 2003. Studi tentang pengeringan cabai dengan alat pengering listrik buatan lokal [skripsi]. Medan: Fakultas Pertanian, Universitas Sumatera Utara.

Taib, G., Gumbira Said, dan S. Wiraatmadja. 1988. Operasi Pengeringan pada Pengolahan Hasil Pertanian. Jakarta: PT Mediyatama Sarana Perkasa.

Tambunan, A. H., D. Wulandari, E. Hartulistiyoso, dan L. O. Nelwan.
2001. Pengeringan Industrial. Terjemahan dari: Sekamon Devahastin. Bogor: IPB Press.

Unadi, A. 2000. Evaluation of Strategies For Drying Tomatoes In A Tunnel Dehydrator. Ph.D. [thesis]. Melbourne: Faculty of Civil an Environmental Engeneering, The University of Melbourne.

Utomo, T. 1984. Teori Dasar Fenomena Transpor. Bandung: Binacipta.

Vitarini, R. 2003. Mempelajari karakteristik pengeringan cabai merah (Capsicum annum L.) dengan menggunakan microwave [skripsi]. Bogor: Fakultas Teknologi Pertanian, Institut Pertanian Bogor.

Wardani, N. Jamhari H.P. 2008. Teknologi Budidaya Cabai Merah. Balai Besar Pengkajian dan Pengembangan Teknologi Pertanian. Badan Penelitian dan Pengembangan Pertanian.

Winarno, F.G. 1984. Kimia Pangan dan Gizi. Jakarta: Gramedia 